\title{
On the Difficulty of ascertaining the Age of certain Species of Trees in Uruguay, from the Number of Rings
}

\section{David Christison M.D.}

To cite this article: David Christison M.D. (1891) On the Difficulty of ascertaining the Age of certain Species of Trees in Uruguay, from the Number of Rings, Transactions of the Botanical Society of Edinburgh, 18:1-4, 447-455, DOI: 10.1080/03746609109468080

To link to this article: http://dx.doi.org/10.1080/03746609109468080

曲 Published online: 01 Dec 2010.

Submit your article to this journal $\pi$

Џ Article views: 3

Q View related articles $\llbracket$ 
On the Diffculty of ascertaining the Age of certain Species of Trees in Uruguay, from the Number of Rings. By David Christison, M.D. (Plate IV.)

(Read 13th March 1890.)

Until comparatively recent times it seems to have been accepted as a truth, alike by botanists and foresters, and perhaps without much thought on the subject, that the number of rings or zones of wood in an exogenous tree, in any part of the world, accurately corresponds with the years of its age. Even now I have met with not a few intelligent botanists who still believe this. Great reliance is also placed, even in the best text-books on forestry, upon the rings as being indicative of the age, and consequently of the important point of the rapidity of growth, in tropical trees. Nevertheless, in recent years it has been shown that in parts of the United States of America, which are not even subtropical, the rings may be more numerous, or even less numerous, than the years of age of trees. Sir Robert Christison also pointed out, about twelve years ago, that in sections of tropical trees examined by him the rings were confused, irregular, and far too numerous to correspond with the age; and, as it has been proved by experiment in Germany that two rings can be produced artificially in a single year, by stripping a tree of its leaves in midsummer, it seems probable that in certain climates the same result may be produced naturally, and that in very equable warm climates, where there is no marked annual check to vegetation, rings might be expected to be formed very irregularly, if at all. Even in temperate countries like our own, although as a rule the zones of wood agree with the years of age, yet I believe it has been ascertained that there are exceptions, arising from temporary injury or in old age, from the layers of wood ceasing to be produced at the lower part of the trunk.

As this is a field of inquiry which as yet has been but little worked, I have brought before the Society the following observations on some sections of trees sent to me last autumn, by $\mathrm{Mr}$ Charles E. Hall, from his estancia of San Jorge, in Central Uruguay. In the first place, however, I shall give a 
brief account of the nature of the country and climate in which these specimens were grown, derived partly from information furnished by $\mathrm{Mr}$ Hall, partly from notes taken by myself during a visit to San Jorge in 1867 , and published in the Transactions of this Society, vol. xiii., 1877--78, and elsewhere.

The estancia of San Jorge is situated near the centre of the Republic of Uruguay, in $56^{\circ} 8^{\prime} \mathrm{W}$. long. and $32^{\circ}$ $43^{\prime}$ S. lat., and at an elevation varying from about 280 to 400 feet above the sea-level. In common with the greater part of Western and Southern Uruguay, the ground undulates in broad-backed ridges, rarely above 60 or 70 feet in height, with exceedingly gentle slopes, to the intervening hollows. The country is on the whole fairly well watered, and the soil is, for the most part, either a deep black stiff rich clay, or light black intermixed with sand, with patches of gravelly soil.

The undulating "campos" are entirely destitute of natural wood, but the edges of the streams are fringed with trees, which, few and scattered in the upper waters, form on the larger streams dense continuous belts, the so-called "montes," permeated by nullahs, and liable to inundation. Useful trees grow in these montes, but, as might have been expected, and as Mr Hall found by experiment, they do not thrive when transplanted to the comparatively dry campos.

The estancia of San Jorge, originally 330 square miles in extent, was broken up, and the Head Station, with 9 square miles of land, became Mr Hall's property in 1876. The "Quinta," or garden ground round the house, then contained about 350 Robinia, Lombardy poplar, and Paraiso (Melia azedarach) trees, besides a great variety of fruit trees. The quinta was at that time the wonder of the whole country for many leagues around, as very few of the estancias, particularly those owned by natives, had vegetable gardens, and still fewer fruit or ornamental trees; and $\mathrm{Mr}$ Hall is, I believe, entitled to the honour of being the pioneer of treeplanting for business purposes on the naked campos of Uruguay. It was in July 1880 that he commenced, and he has now 160 acres under plantation, carrying about 80,000 trees, the great majority being Robinia pseudoacacia, Lombardy poplar, and Acacia melanoxylon (Blackwood). 
Mr Hall's example has not yet been extensively followed in Uruguay, as he informs me that, within a circuit of fifty miles, the estates that have so much as twenty acres planted could probably be counted on the fingers of one hand, while very few have as much as an acre, and the great majority are still quite bare of wood. It is to be expected, however, that a great change in this respect will take place when the encouraging results of $\mathrm{Mr}$ Hall's planting are more generally known; and I am glad to say that it is his intention to publish shortly a full account of his forestry experiments in Uruguay.

Meteorological observations were taken by Mr Hall with tested instruments, properly protected, and according to recognised scientific rules. The principal results are as follows:-

The climate is variable, and the extremes of temperature and rainfall are accentuated. Long droughts and longcontinued rains are apt to occur. The annual rainfall is irregular in amount; thus, for the two years from July 1886 to June 1888, it was in all $32 \frac{1}{2}$ inches, but for the subsequent year it was no less than 79 inches. The annual average number of days of rain is 94 , and the fall is torrential in character. April and September are the rainiest months, and February the driest.

December, January, and February may be taken as the summer months, the average maxima of temperature being $84^{\circ} \cdot 7 \mathrm{~F}$., the minima $58^{\circ} \cdot 4$. June, July, and August are the winter months-average maxima $60^{\circ} \cdot 5$, average minima $41^{\circ} \cdot 3$. The spring and autumn average maxima and minima are much alike-maxima $72^{\circ}$, minima $49^{\circ}$. Highest temperature in shade in nine years, $100^{\circ}$; lowest, $23^{\circ}$. Mean annual temperature, $60^{\circ} \cdot 9$. Frost at night is not at all infrequent in winter, but it disappears as the sun gains strength in the early morning.

It thus appears that the cold season is sufficiently well marked to lead us to expect a distinct annual check to vegetation, and that, in the warm season, temperature and rainfall are liable to sudden marked changes, from which minor effects on the growth might result.

The five sections sent by $\mathrm{Mr}$ Hall are from five species of trees, and were all cut close to the ground. I give

TRANS. BOT. SOC. VOL. XVIII. 
some of their chief characteristics, together with the duration of the seasonal-growth of the species to which they belong, from monthly girth-measurements of other trees of their species taken for several years by $\mathrm{Mr}$ Hall.

Robinia pseudoacacia, Lin.-Age, ten years; annual girthincrease of the specimen, $1 \frac{1}{2}$ inch ; winter sleep of the species, six to eight months, during part of which, however, there was a very slight growth.

Melia azedarach.-Native of Syria, but naturalised in South Europe (Lind.); a favourite boulevard tree in Spanish South American cities, there called "Paraiso." Age, eleven years; annual girth-increase of the specimen, 2.27 inches; growth ceased, or was greatly retarded in the species for from four to six months annually; in 1888, after a good start in August, the rate fell greatly in September and October.

Acacia dealbata v. mollissima, Willd.-Evergreen; native of Australia. Age, seven years; annual girth-increase of specimen, 1.97, but that of two other of the species was 5 inches; growth of the species pretty steady through the year, except a total cessation from 12th February to 12th March in 1886, from 12th December to 12th January in 1886-87, and from 12th January to 12th February 1888.

Acacia melanoxylon, R. Br.-Black wattle; native of Australia. Age, eight years; annual girth-increase of the specimen, $3 \frac{1}{4}$ inches; growth of the species much retarded for two to three winter months in 1886 and 1887, and ceased entirely for two months in 1888.

Acacia lophantha, Willd--Deciduous; native of Australia. Age, five years; annual girth-increase of the specimen, 4 inches; growth of the species unknown.

Before proceeding to describe the rings in these sections, it will be well briefly to recall the characteristies of rings in hardwood trees of temperate climates.

1. Perhaps the most invariable differentiating character is the difference in density between the spring and autumn wood, the former being much looser in texture than the latter. This is very evident under the microscope, but often shows a marked distinction to the naked eye also.

2. At the outer side of the autumn wood there is usually, as it were, a rather sudden and extreme compression or flattening of the tissue, as seen under the microscope, which forms the 
sharp line of demarcation, visible to the naked eye, of the zones of wood in so many of our forest trees.

3 . This line of demarcation is, in many species, accentuated by an aggregation of the vessels into a circle close to the inner edge of the spring wood; but in other species this character is wanting, as the vessels are distributed more equally, often in successive circles, through the zone. The cut mouths of the vessels are generally quite visible to the naked eye.

\section{Character of the Rings in the Specimens to the Naked Eye.}

Robinia pseudoacacia.-On the dark smoothened surface of the block, ten thin whitish circles sharply mark out eleven zones of wood, corresponding with the known age of the specimen. These circles are caused by the presence of the second and third characteristics noted above. A large number of very distinct concentric rings are also caused by a tendency to a circular arrangement of the vessels throughout the zones, but there is no risk of these being mistaken for annual zones.

Melia azedarach.-On the smoothened, reddish-brown surface, nine whitish concentric lines, at tolerably regular intervals, are clearly marked, besides eight others confined to the inner radius of half an inch. Judged by a British standard, therefore, we should pronounce this tree to be eighteen years old, the earlier eight years' growth having been very slow, as we often see. But the actual age of the tree is only eleven years. Besides these solid-looking circles, there are upwards of 100 very distinct quasi-circles, formed of innumerable vessels with whitish walls.

Acacia melanoxylon.-The smoothened surface shows a series of concentric waves, alternately whitish and brownish, very numerous, and with no sharp lines of demarcation. At intervals, two or three of the brownish waves are broader and darker, and thus vaguely define eight zones of wood, corresponding in number to the years of age of the tree. The two inner of these vague boundaries are of a wavy blackish-brown all over. The vessels are small, numerous, and not in rows.

Acacia mollissima. - The smooth surface shows a large 
number of concentric waves, as in the last, distinct enough, yet too vague to be counted accurately. Groups of three or four, more distinctly marked, occur, but they do not in the least correspond with the age of the tree. Judged by a British standard, the tree might be considered to have badlymarked rings, occasionally arranged in more distinct groups of two or three, indicating, from the more distinct lines alone, an age of about twenty years, but it is only six and a half. In the illustration, Plate IV., which I owe to the skilful pencil of Mr Gustav Mann, the natural appearance is shown in the finished part of fig. 1 ; but the lines of demarcation of the first five years are accentuated to show their position better. The sixth line has not been so treated, as it is scarcely possible to make it out.

Acacia lophantha.-The smooth surface shows about forty concentric waves, very distinct at a glance, but with no sharp definition, and difficult to count. They do not differ much in distinctness, except a well-marked dark one near the centre.

The general results, so far as naked-eye surface characteristics of the blocks are concerned, are, that the zones are quite distinct, reliable, and annual in Robinia; that in Melia zones are clearly marked out, but are considerably more numerous than the years of age of the tree; that in Acacia melanoxylon the annual zones are vaguely marked by an accentuation of colour in certain groups of numerous rings which are not annual; that in $A$. mollissima and lophantha the annual zones are either unrecognisable, or are only to be made out with difficulty and doubt, amidst the numerous wave-like rings.

\section{Microscopical Appearances.}

It remained to ascertain whether, in the instances in which the rings were indistinct or unrecognisable to the naked eye, the true annual rings could be made out by aid of the microscope. Fine sections were accordingly made of Acacia mollissima and lophantha by Dr Macfarlane, and I had the advantage of his assistance in examining them. As the results in the two species were not materially different, I shall confine my observations to the Acacia mollissima, as 
the appearances in it are illustrated by $\mathrm{Mr}$ Mann in Plate IV. Fig. 2 shows the characteristics of a well-marked ring, the fifth. The somewhat gradual flattening or apparent compression of the latest autumn wood of the fourth year (a) into a circle forming a distinct line of demarcation is well shown, and the larger size of the cells of the spring wood of the fifth year (b), particularly at the very commencement, is noticeable. The differences, however, in density of tissue and size of lumina are not nearly so well marked as is ordinarily the case in the wood of temperate climates. In fig. 3, which shows the demarcation between the first and second year's growth, the comparative feebleness of the characteristics are seen; and it may be remarked that in other parts of this ring, as well as in other true rings both of Acacia mollissima and Acacia lophantha, the band of flattened cells almost, if not entirely, disappears. Fig. 4 shows the very slight differences between the older tissue $(a)$ and the younger $(b)$ in a false ring.

Thus we have a transition from the well-marked annual ring of the fifth year, through the feebly-marked annual ring of the first year, to the almost insensible impress of a seasonal variation-all, no doubt, due to the influence of varying degrees of heat or moisture, or both combined. And if these results occur in a climate with a well-marked summer and winter season, we are at no loss to account for the confused and numerous rings noted by Sir Robert Christison in tropical wood. His observations, however, were only with the naked eye, and it is much to be desired that the nature of the wood-rings in tropical dicotyledons should be thoroughly investigated by aid of the microscope.

Taking a general review of the results, the following conclusions may be drawn:-

1. The ages of the specimens cannot be determined with certainty by counting the rings on the blocks, except in Robinia. In Melia, zones of wood, sharply defined by lines of demareation similar to those met with in our British trees, are seen, but the zones exceed in number the years of age of the tree. In the Acacias a series of wave-like rings greatly surpass in number the years of age of the trees, and it is difficult or impossible to pick out the true demarcation of the yearly growths. 
2. In the two Acacias-mollissima and lophantha-which were examined microscopically, true lines of demarcation, although doubtful or invisible on the block, could be made out by the naked eye in transparent sections, but sometimes only with difficulty and after verification by the microscope. Even under the microscope the line of demarcation was sometimes feebly marked, and the distinction between the autumn wood on one side and the spring wood on the other was very slight.

3. In proportion to the shortness or imperfection of the winter rest in the different species, the demarcation of the zones appears to become less marked. Thus, in Robinia, which enjoys a long winter sleep, the demarcation of zones is quite distinct on the blocks, and the minute structure of the parts which contribute to the differentiation of the zones differs but little from that of our British trees. But in the Acacias, which have a short and, perhaps, in some seasons, little or no rest, the demarcation of zones is often difficult, doubtful, or even indistinguishable on the block, is seen with difficulty by the naked eye in thin sections, and is comparatively feebly marked, in some instances, under the microscope.

4. Quasi lines of demarcation, consisting of vessels arranged in concentric circles, are met with in Melia and Robinia. They are easily distinguished, even by the naked eye, from the true lines of demarcation, and do not form the limits of zones differing in appearance or minute structure from each other. In the Acacias there is a tendency to the same concentric arrangement of the vessels, but they make no show on the block, and the ringed appearance in these specimens is perhaps mainly due to numerous concentric zones of for the most part slightly-differing shades of colour. Under the microscope these false rings are perhaps distinguishable, but only by very trifling differences in the tissue indeed.

It is interesting to note the variety in the duration of the winter rest in the different species of trees measured by Mr Hall. It is his intention to show this fully in a paper upon the results of his tree measurements, to be read to our Society in the present Session. In this place it is sufficient to point out that trees introduced from England enjoy as long a winter rest as at home; that Melia azedarach, a native of Syria and naturalised in the South of Europe, and Robinia 
pseudoacacia have a shorter repose; and that the Acacias, natives of the still hotter Australia, only rest for a few weeks, in some seasons perhaps not at all. Thus each species appears to follow the practice of its ancestors, although all are now living under the same atmospheric conditions.

In conclusion, I may point out the desirability of making some distinction between the annual growth of wood and the line of demarcation between two annual growths. It is true the latter is a vague element which cannot be easily defined. Still it is often of practical utility in ordinary speech. Perhaps the annual growth might be called a zone, and the line of demarcation a ring.

\section{EXPLANATION OF PLATE IV.}

Fig. 1. Surface of a section of a stem of Acacia mollissima, $6 \frac{1}{2}$ years old. Natural size. The line of demarcation between the 6th and 7 th year's growth is pretty strongly indicated to show its position, but is very feebly marked on the block, as shown in the finished part of the drawing. It is also very feebly marked microscopically.

Fig. 2. Junction of the 4th and 5th year's growth. Transverse section. Jllustrates the structure of a true ring, $\times 600^{\circ}$. (a) 4th year's wood ; $(b$.) 5th year's wood.

Fig. 3. Junction of the 1st and 2nd year's growth. Transverse section. Illustrates a less strongly marked true ring. Bounded on each side by a medullary ray, $\times 400^{\circ}$. (a) 1st year's wood; (b) 2nd year's wood.

Fig. 4. Transverse section of a false ring, between the 2nd and 3rd true rings, $\times 400^{\circ},(a$. $)$ older wood; $(b)$ younger wood, Bounded on each side by a medullary ray. 


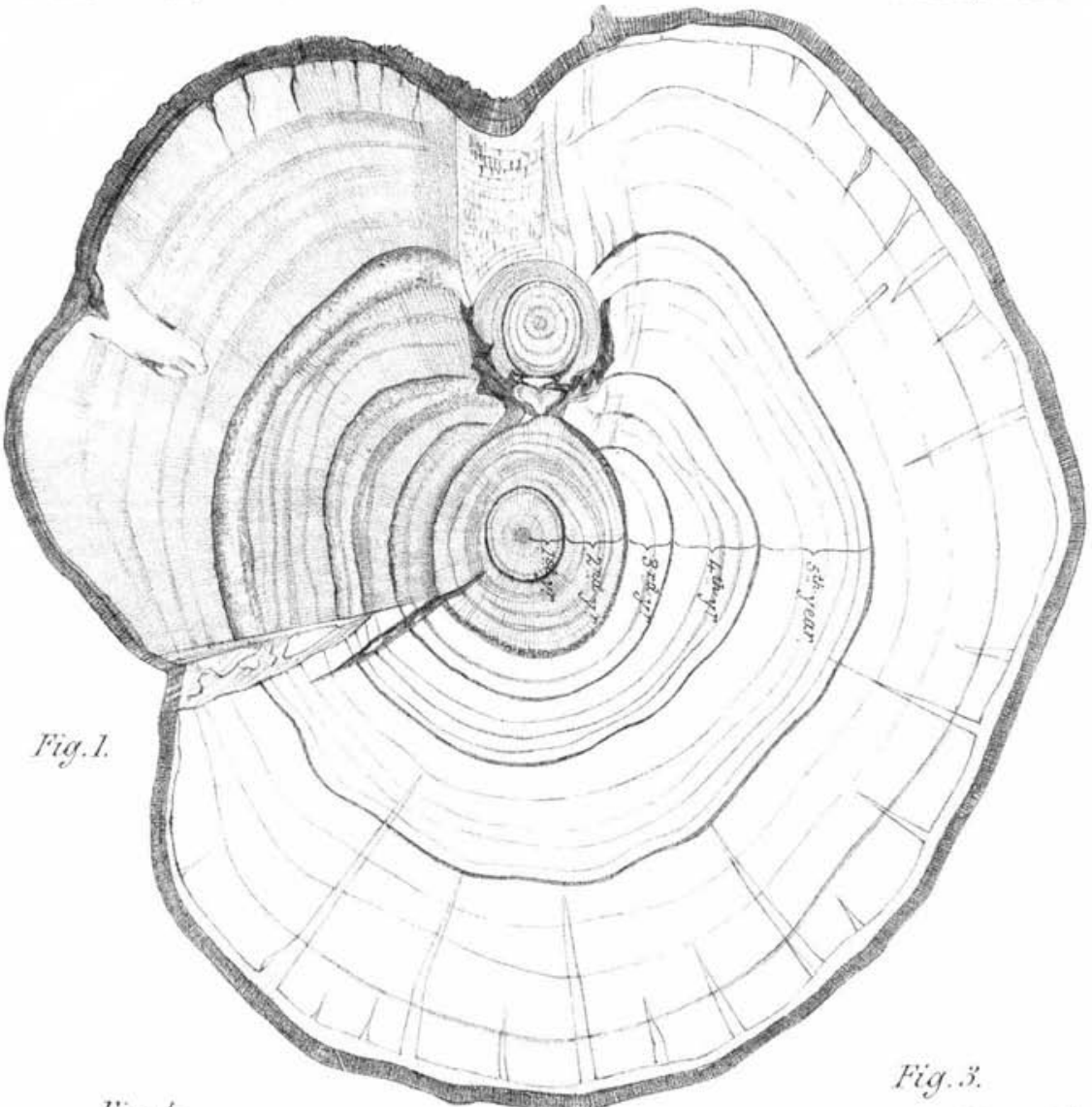
Fig. 4.
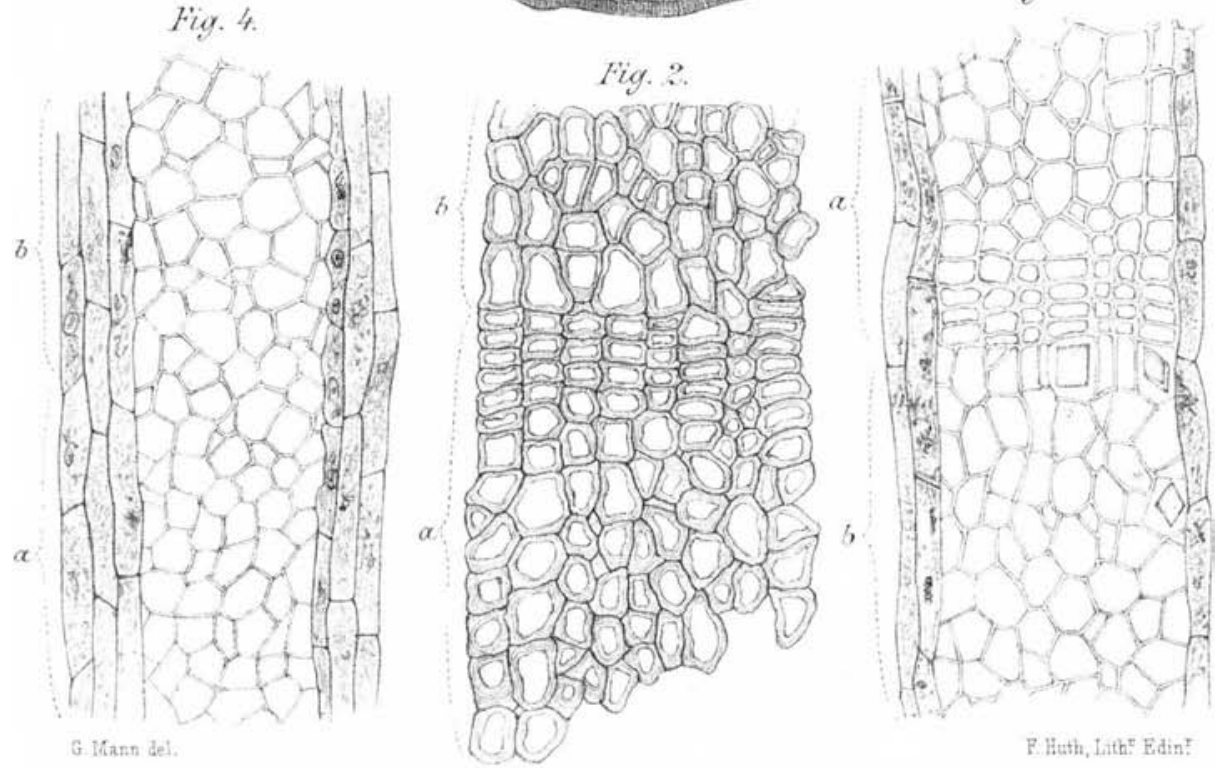